\title{
Dynamics of Accounting Theory and Practice: Accounting Issues of Loan Loss Provisioning and Measurements of Financial Instruments of Nigeria Qouted Banks
}

\author{
Odoemelam Ndubuisi \\ Department of Accounting, Faculty of Business Administration \\ University of Nigeria Nsukka \\ Email: endy_doc@yahoo.com
}

Received: April 28, 2016 Accepted: June 07, 2016 Published: June 11, 2016

doi:10.5296/ijafr.v6i1.9393 URL: http://dx.doi.org/10.5296/ijafr.v6i1. 9393

\begin{abstract}
This research examines the changes in theory and practice of loan loss provisioning (LLPs) under IFRS and CBN prudential guideline and banks classification and measurement of financial instruments in the balance sheet by listed Deposit Money Banks (DMBs) in Nigeria. Data were drawn for a period of six years (2010-2015) post -IFRS. The data were analyzed using simple percentages, graph and tables to empirically investigate the difference between the IFRS and CBN provisioning models. Banks were grouped into two, the too-big-to- fail banks and smaller- banks. The findings, $i$ observed that both groups adopt mixed attribute accounting (MAA) model in classifying and measuring financial securities and that the dynamic forward looking LLPs that will replace IAS 39 is a right decision by standard setters. Analysis of the data showed a clear stand of IASB and CBN, while the former emphasize on transparency the later is interested on stability of the financial industry. The study recommended that accounting principles and rules should be harmonized to reduce diversities of professional judgment and discretion in financial reporting. There should be synergy between the regulators and accounting standard setters (CBN and IASB). The stability of the financial system and providing faithful and relevant information to investors and other segments of the society should be a paramount objective of the two bodies and preparers of financial statements.
\end{abstract}

Keywords: Loan loss provisions, Assets, IFRS, CBN, Deposit money bank, Nigeria. 


\section{Introduction}

Economic instability, corruption, corporate collapses, fraud, investor uncertainty, transparency and sustainability are today driving a number of accounting issues that call to question accounting theories and practices with regard to the value and appropriateness of traditional and modern accounting thinking and structures. The published financial statements of entities worldwide should stand in as 'financial bible' that communicates information about the entity's economic resources and claims to those resources and changes in those resources and claims (Kieso et al, 2010). This relevant and faithful information as represented will aid the end users to make informed economic decisions (Glautier et al, 2011). Investors have been misled by some financial information contained in various entities' financial statements. Ezejelue (2004) stated " that the purpose of accounting should not be to deceive but to show truthful and reliable balance sheet values that will harmonize with economic reality so as to exhibit the real net worth and enable a time and reliable income statement to be presented". The cases of Enron Corporation, Washington Mutual Bank in September 2008, Royal Bank of Scotland Group Plc and Arthur Anderson Accounting firm are few examples of fraudulent financial reporting in other countries of the world. In Nigeria, there are quite a number of cases of misinforming the investors and other segments of the society about the financial positions of entities that are involved. For instance, Intercontinental bank plc, Oceanic bank plc and Afribank plc were alleged of manipulating their financial statements. In the case of Intercontinental and Oceanic banks, the loan loss provisions as per Central Bank of Nigeria (CBN) were 278.2 billion naira and 210.9 billion naira as against 36 billion and 16.6 billion naira as per audited accounts respectively. Afribank draft accounts indicated a loss of 6.9 billion naira while 2.94 billion naira was reported (Olusanya 2010 and Oni 2007 cited Angahar, 2012). It is as a result of these challenges and the dynamic nature of the environment facing financial reporting and management that accounting theories and practices evolve in search of solution to the real world accounting problems. According to Kieso et al (2010) "accounting theory and practice have always evolved and will continue to evolve". Therefore, as long as accounting theory and practice evolve based on trial and error, there will always be problems to be solved by standard setters and theories are bound to change.

Theories always try to explain with reason, the logic underlying a particular practice. As noted by Wall and Koch (2008) at least three different philosophies on loan loss accounting exist. They are economist's view, FASB's view and the capital view. The economist viewed loan loss allowance as the provision intended to capture future losses that will occur if borrowers default. While Financial Accounting Standard Board's view is the measurement of a firm's net income over a given period, on the other hand the capital view sees loan loss allowance as an element of capital.

Blaanw (2009) stated that initially accountants were in agreement with regulators favoured system of loan loss provisioning based on expected losses. But accounting standard setters finally accepted an incurred loss based methodology when the standard became effective in 2005. Blaanw (2009) further noted "not all countries, however followed the incurred loss approach. The Spanish regulator for example adopted a dynamic provisioning framework 
based on expected loss" that Spanish was able to withstand the global financial meltdown of 2008 (Blaanw, 2009).

Accounting for loan loss has been an issue over the years. The paragraph 59 of Financial Accounting Standard No. 5 stated it clearly that loan loss provision should be based on incurred loss reflecting events that happened within the financial year. In Nigeria, today, according to CBN (2013) provisions under prudential guidelines are determined using the time base provisioning prescribed by the Revised Central Bank of Nigeria (CBN) in 2010. Under the IFRS Model, credit impairment is measured using the provisions of IAS 39 which requires fair value for financial instruments other loans and receivables that are not held for trading, securities held to maturity and qualifying hedges. This treatment of loan loss accounting has generated much debate with its front liners US GAAP and UK IFRS standard setters. To overcome the challenges of IAS 39, loan loss provision is to be based on expected loss model-IFRS 9. Nigerian banks are yet to use the IFRS expected loss model. Therefore the banks in Nigeria are required to comply with the following:

a) Provision for loans recognized in the profit and loss account should be determined based on the requirements of IFRS. That IFRS provision should be compared with provisions determined under prudential guidelines and the expected impact changes in general reserve should be treated as follow:

(i) Prudential provisions is greater than IFRS provisions; the excess provision resulting should be transferred from general reserve account to a regulatory risk reserve.

(ii) Prudential provision is less than IFRS; IFRS determined provision is charged to the statement of comprehensive income. The cumulative balance in the regulatory risk reserve thereafter reversed to the general reserve account.

b) The non -distributable reserve should be classified under Tier 1 as part of the core capital(UBA Annual Report 2012 and CBN, 2013)

On the issue of financial instruments (Assets) Elmeraji (2008) noted that "certain type or securities (like level 3 assets) discretion plays a big part to what you see on a company's books". Laux and Lenz (2000) argued that after all, the biggest position on the bank balance sheets (financial position). The held-for- investment loan portfolio is not subject to a fair value according on both balance sheet or income statement and that it is subject to weaker impairment standards.

Previous surveys and empirical analysis have explored the issues from the perspective of earnings and capital management. These studies estimated the amount of the loan- loss provisions required to cover - expected loss and treat the remaining provision as what is called discretionary loan - loss provision. In their various studies, they found that banks use loan loss accounting to manage capital and earning (Collins, Shackelford and Wahlen 1995 Moyer 1990; Ahmed et al 1999; Breathy, Chamberlin and Mayloolo, 1995; Ahmed et al 2014 and Ozili 2014). On the other hand Okaro and Okafor (2013) in their study on fair value accounting and loan loss provisioning - early evidence from Nigeria banking industry, agreed that fair value allow banks to increase their leverage in periods of boom and the expectation 
why CBN revised prudential guideline of 2010, that banks abuse loan loss provisioning and was bound to produce more aggressive figures as loan loss provision.

Therefore, based on this background, the objective of this study is to examine the dynamic theories and practices of loan loss approving and measurements of financial securities (assets) of quoted banks in Nigeria.

\subsection{Statement of Problem}

According to Katudu (2008) the all-important duty of measuring and disclosing information obligation in line with accounting standards has been a subject of debate and controversy in recent years. Taking cognizance of the crumbling and demise of companies like worldcom Inc, Enron, Washington mutual bank, Oceanic bank of Nigeria, Intercontinental bank Plc, Afri bank of Nigeria and host of other renowned accounting firms indicted for not carrying out their duties in a professional manner. In the words of Kerr (2013) "the potential misreporting involved is significant. UK bank, Royal Bank of Scotland Group Plc, I and other calculated that IFRS rules resulted in the bank understating its 2011 losses by 19.5 billion pounds". The IFRS model of loan loss provisioning presently in use has raised many issues, Kerr (2013) noted that official of IASB has acknowledged the problem, saying that banks should maintain two profits calculations, one for reporting to shareholders, and the other not following IFRS rules to determine distribution to shareholders. He questioned this idea that it is false accounting

\subsection{Objectives of the Study}

The objective of this study is to provide empirical evidence of loan loss models of both incurred and expected, this also examined the accounting treatment of financial instruments (assets) of quoted banks in Nigeria. To achieve the purpose of the study the following objectives and pursued.

1. To determine the difference between CBN Expected loss model and IFRS incurred model of quoted banks.

2. To express the difference between the CBN Expected loss model and IFRS incurred loan loss model as a percentage of the Tier 1 capital of quoted banks in Nigeria.

3. To ascertain the difference in application of these expected and incurred loan loss models by too - Bib. To fail banks and small banks quoted in Nigeria stock market,

4. To examine the key assets on the financial positions of Nigeria banks as a fraction of their total assets.

\subsection{Significant of the Study}

This study contributes to the accounting literature which suggests that managers and accountants have various incentives for choosing and influencing some accounting numbers, in this case loan loss accounting, fair value accounting, historical cost accounting and mixed attribute accounting model for financial instrument. The findings of this research will be relevant to current concerns of accounting standard setters and bank regulators on the current 


\section{Macrothink \\ International Journal of Accounting and Financial Reporting \\ ISSN 2162-3082 2016, Vol. 6, No. 1}

model of loan loss provisioning.

\subsection{Scope of the Study / Limitation}

The theoretical area to be covered in the study is restricted to literature on loan loss accounting and accounting treatment of financial instruments. The study was based on listed banks in Nigeria that have adopted IFRS between 2010-2015. The research is subject to a number of limitations. The study is limited to the money deposit banks (MDB) in Nigeria banking sector. Few banks not been able to release their financial report up to December, 2015 (i.e. Diamond, FBN).

\section{Theoretical / Conceptual Framework}

In the introductory part of the study, we noted that theory and practice of accounting evolve by error and trial. This implies that accounting theory and practice are changing in line with dynamic nature of the environment. Bank for international settlements is strongly in support of IASB to change the present incurred loss provisioning to expected loss approach (BIS, 2010). Andrew (2014) lends his view and support to expected loss provisioning, said that under the current international accounting standards provisions are based on incurred risks than expected losses. He stated that implementation of the new accounting standard for provisioning, IFRS9 is a step in this direction." To buttress the point why loan loss forward looking provisioning is preferred to backward looking loan loss provisioning, Beatty (2009) noted that backward looking loan loss provisioning will lead to an increase in the required provision during economic downturn. He further said, this increase in the loan provision will decrease bank's reported income and their Tier 1 regulatory capitals. The practice of accounting worldwide is guided by set of rules, customs and conventions (Ezejelue, 2004). These rules and guidelines are compiled into accounting standards. Two set of bodies govern the accounting practice in Nigeria. They are:

1. Financial Reporting Council (FRS) that replaced Nigeria Accounting Standard Board (NASB).

2. International financial Reporting Standards (IFRS) which are issued by the International Accounting Standard Board (IASB).

\subsection{Theory of the Firm}

Some scholars have questioned that many underlying theories of accounting are by other scholars from other disciplines. One of such theories is the theory of the firm which is potentially relevance in discussing accounting issues. For instance, questions of measurement in financial reporting. ICAEW (2010) in their study titled "business models in accounting, the theory of the firm and financial reporting information for better market initiative", acknowledged that it is difficult to make a direct connection between the theory of the firm and accounting measurements, but they " argue that one way of relating the two to each other is via firm's business models" ICAEW (2010) stated that "assumptions about business models have always been the case that different business will account for the same asset in different ways depending on what its role is within the firm's business model. This is not far 


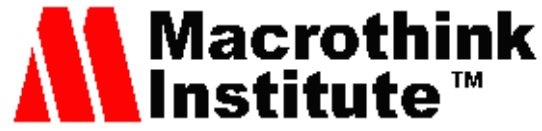

International Journal of Accounting and Financial Reporting

ISSN 2162-3082 2016, Vol. 6, No. 1

from the views or Laux and Lenz (2010) and Doron and Stephen (2008). ICAEW (2010) further stated that historical cost and fair value accountings are among other approaches of reflecting firm's models. In the study, ICAEW categorically stated that it is "impossible to devise a sensible approach to financial reporting measurement that does not reflect firm's business models".

\subsection{Concept of Historical (Original) Cost Accounting}

Trueblood Committee in its report in 1973 suggested seven qualitative characteristics of financial statement which includes: relevance and materiality, form and substance, reliability, freedom from bias, comparability, consistency and understanding (Enahoro and Jayeoba, 2013).

Historical cost accounting (HCA) records assets and liabilities on a firm's balance sheet at original cost (which in the beginning should be equivalent to fair value). These assets and liabilities are been amortized to reflect passage of time. HCA is interested in recording realized cash flows to measure to measure changes in the financial condition of the firm. According to Richard most financial institutions prefer HCA to FVA because it provides them with considerable flexibility over the timing of the recognition of gains and losses (http://fic.whartron .unpenn.edu/fic/papers/11/11-72.pdf).

Generally Accepted Accounting Principle (GAAP) requires that most assets and liabilities be accounted for and reported on the basis of acquisition price. This method often referred as historical cost principle has an advantage over other valuations. The advocates of this method said it is reliable. Users of historical cost accounting have indicated a preference for it because it provides them a stable and consistent benchmark that can be relied upon to measure historical trend. HCA recognizes gains and losses only when actually realized.

In the 1980, accounting standard setters began to shift away from this approach in part due to concerns that the combination of historical results disconnected from economic reality (Shaffer, 2011). Those against historical cost are of the opinion that it encourages managers to smooth profits through hidden, excess reserves and selective sales of securities. Also the fact that historical cost was proving to be a poor measurement approach in inflationary markets for instance, new financial products such as derivatives and structured investments simply could not be measured in a meaningful way using traditional approach (Shaffer 2011)

\subsection{Concept of Fair Value Accounting}

Fair value accounting focuses on the price that would be received to sell the asset or paid to transfer the liability (an exit price) not the price that would be paid to acquire the asset or received to assume liability (an entry price ) (Oxford Dictionary of Accounting 2005). Many of Nigeria banks have started reporting their financial statement based on international Financial Reporting Standards (IFRS). Financial Reporting Council of Nigeria (FRC), the body that is saddled with the responsibility of setting accounting Standards in Nigeria, approved the adoption of IFRS through the Federal Executive Council (FEC) in September, 2010. Implication of the adoption of IFRS is the use of fair value accounting. This new wave of fair value accounting though been criticized by many has gained much disciples (Rock, 


\section{Macrothink}

Elena and Sarlat, 2009)

Bob Herz, FASB's chairman carrying the "gospel of fair value accounting argues that fair value is "essential to provide transparency for investors (Kambayashi, 2008). The Nigerian Standard setters, FRC has joined the "league of fair value accounting as America's Financial Accounting Board (FASB) and London- based International Accounting Standards Board (IASB) have not budged an inch to drop it. In the same vain, Financial Reporting Council of Nigeria (FRC) sees fair value accounting as an essential guidance that will enhance financial statement reliability (Bala and Hope 2014). But FASB and IASB defense is that enhancing financial stability is not the purpose of accounting (Kambayashi 2008 and Lionel et al, 2008). If the standards setters are correct, the first question that critics ask is what then is the role of accounting?

\subsection{The role of Accounting}

Lionel et al (2008) exploring the ignorance of the main issue about fair value accounting, maintained that accounting has a role as a source of information, removing this information that fair value account provides on the pretext of lessening the procyclcality of accounting would reduce transparency and deepen the crisis of confidence. The second question posed by the critics of fair value is how to value illiquid (and sometimes unique assets). A common solution is to use bank's own models. It is worrisome that there is no streamlined method of valuation. Ezejelue (2004) stated that "accounting exists in a world of uncertainties and alternative methods". He further stated that "this makes financial statements not only flexible but also reliable for some purposes and unreliable for others". This assertion confirms the concerned of investors as noted by Kambayashi (2008) "but some investors are concerned that this gives banks' managers too much discretion and no wonder, because highly illiquid (or "level 3") assets are worryingly large relative to many bank shrunken market values" he further noted that it may not be possible to find a generally acceptable method. It is very obvious that lack of acceptable method or single consistent framework for applying fair value measurements and developing a reliable estimate of fair value in the absence of quoted prices have created inconsistencies and incompatibility. Entity's (Bank) today based on the theory of the firms that is linked to business model determines the treatment of financial assets based on its intention. Contributing to this Ezejelue (2004) stated that the choice is visually that of the manager or the accountant or both. Based on the policies of and the pressures on, the bank management may adopt methods, which will render the financial statement aggressive, or conservative, or liberal "these issues call for urgent guidance by IASB to come up with a well acceptable framework or standard that can be used in fair value measurement.

\subsection{Classification and fair value of Assets and Liability}

The most widely used method of classification of assets and liabilities as observed from the financial statements of banks in Nigeria show a combination of HCA and FVA, which result to mixed-Attribute Accounting (MAA). See table 1 figure 1 and table below. 


\begin{tabular}{|c|c|c|c|}
\hline $\begin{array}{l}\text { Classification of } \\
\text { Assets }\end{array}$ & $\begin{array}{l}\text { Disclosure of Value } \\
\text { Assets and Liabilities } \\
\text { of Balance sheet }\end{array}$ & $\begin{array}{l}\text { Inclusion of A fair } \\
\text { Value in reported } \\
\text { Earning }\end{array}$ & Regulatory Capital \\
\hline $\begin{array}{l}\text { Held-to-Maturity } \\
\text { Securities (Debt } \\
\text { securities that firm } \\
\text { has positive intent } \\
\text { and ability to hold to } \\
\text { maturity.) }\end{array}$ & $\begin{array}{l}\text { At amortized cost fair } \\
\text { value may be } \\
\text { disclosed in footnote } \\
\text { to financial statement }\end{array}$ & $\begin{array}{l}\text { Only if judged } \\
\text { impaired (or sold for } \\
\text { value other than } \\
\text { amortized cost }\end{array}$ & $\begin{array}{l}\text { Unrealized losses affect } \\
\text { regulatory capital only } \\
\text { the case of a permanent } \\
\text { impairment }\end{array}$ \\
\hline $\begin{array}{l}\text { Trading Securities } \\
\text { (Debt and equity } \\
\text { bought and held } \\
\text { principally for } \\
\text { purpose of trading in } \\
\text { near term.) }\end{array}$ & $\begin{array}{l}\text { At fair value. } \\
\text { Changes in value } \\
\text { affect equity }\end{array}$ & $\begin{array}{l}\text { Unrealized gains \& } \\
\text { losses affect earnings } \\
\text { and income }\end{array}$ & $\begin{array}{l}\text { Unrealized gains and } \\
\text { losses affect regulatory } \\
\text { capital }\end{array}$ \\
\hline $\begin{array}{l}\text { Available-for-sale } \\
\text { Securities } \\
\text { (The residual-not } \\
\text { classified as held-to - } \\
\text { maturity or trading } \\
\text { securities) }\end{array}$ & $\begin{array}{l}\text { At fair value changes } \\
\text { in fair value recorded } \\
\text { in Accumulated other } \\
\text { Comprehensive } \\
\text { income }\end{array}$ & $\begin{array}{l}\text { Excluded from } \\
\text { earnings, but reported } \\
\text { in a special account, } \\
\text { other } \\
\text { Comprehensive } \\
\text { Income. }\end{array}$ & $\begin{array}{l}\text { Unrealized losses affect } \\
\text { regulatory capital only } \\
\text { in the event of } \\
\text { permanent impairment }\end{array}$ \\
\hline
\end{tabular}

Table 1: Classification of Assets and Associated Accounting Principles

Source: Adopted from R. J. Herring (http://fic. Wharton.upenn.edu/fic/papers/11/11-72.pdf) 


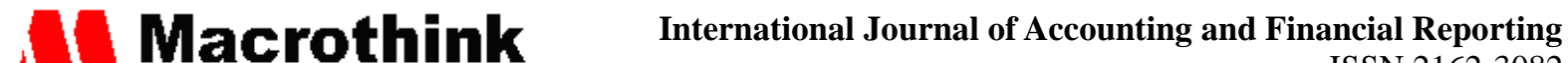

Figure 1

How to Classify and Fair Value Assets and Liabilities

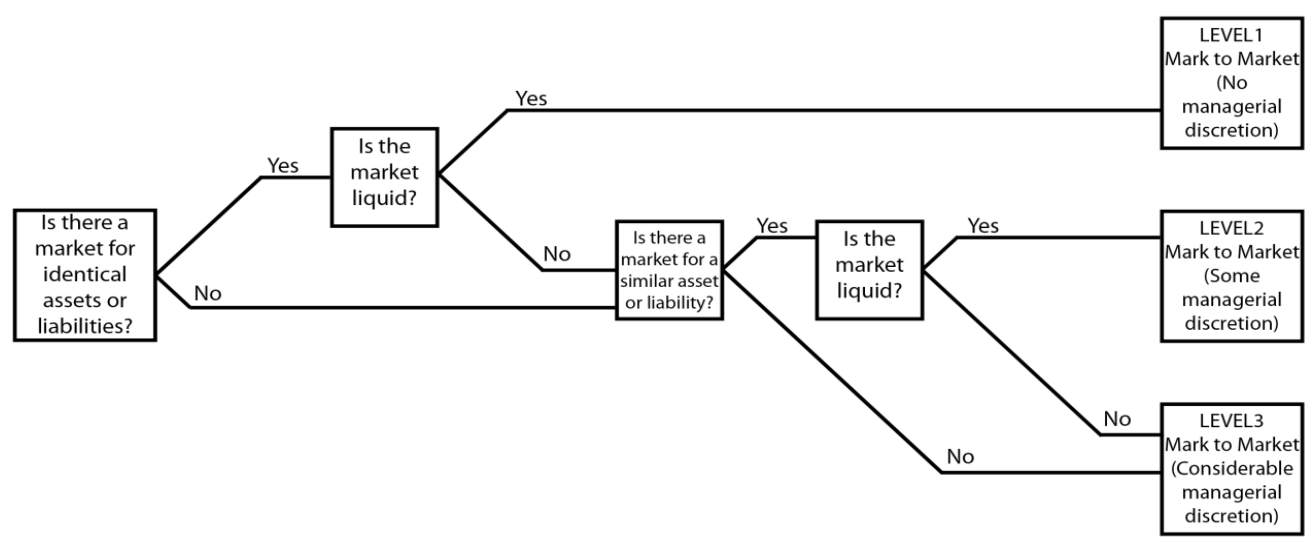

Source: Adopted from R.J.Herring (http://fic.wharton.upenn.edu/fic/papers/11/11-72.pdf)

From the above figure, bank classifies and value their assets based on their intention best known to them (discretion).

Held-to-Maturity (HTM): If bank has the intention of holding a security to maturity, "it may value the asset on its balance sheet using HCA". The amortized cost will be reflected on the balance sheet although the fair value may be disclosed in a footnote. When assets is determined to be impaired permanently the change in fair value is reported in the income statement. "Unrealized losses affect regulatory capital only in the case in which the asset is deemed to be permanently impaired". (http://fic.wharton.upenn.edu/fic/papers/11/11-72.pdf)

Held -for-Trading (HFT): Assets held principally for the purpose of trading in the near term are classified as trading securities and must be fair value. Change in fair value- whether realized or not - are disclosed in the income statement and affect the value of equity. In this instance unrealized gains and losses affect regulatory capital. (http://fic.wharton.upenn.edu/fic/papers/11/11-72.pdf)

Available-for-Sale (AFS): The third category, available -for-sale, is the residual assets that are not classified as held-to-maturity or trading securities. The treatment of this category is a bit complicated. Although the assets are recorded on the balance sheet at fair value, unrealized changes in fair value are excluded from the income statement instead they are recorded in a special account, "other comprehensive income" and reported on the balance sheet as "accumulated other comprehensive income". Unrealized losses affect regulatory capital only in the event that an asset is deemed permanently impaired (Garcia-Feijoo, 2009)

Mixed-Attribute Accounting: Mixed- attribute accounting model for financial instruments allows banks choose the measurement they desire for a position through how they classify the position. For example, under FASB 115 a firm may choose to classify a security as any one of trading, available for sale or held-to-maturity and thereby obtain one of three different accounting treatments (Ryan, 2008). 
2.6. Incurred Loan Loss Provisioning Vs Expedited Loan Loss Provisioning

According to IAS 39, impairment losses are incurred if there is objective evidence of impairment as a result of one or more events that occurred. This requires fair value for financial instruments. Other than loans and receivables that are not held for trading, securities held to maturity, and qualifying hedges. Baauw (2009) in his view incurred loss and expected loss based provisioning, favored the later by calling on Nigeria regulatory authorities to adopt a dynamic loan loss provisioning model based on the expected loss model irrespective of the loan loss provisioning model adopted by IFRS. According to him, Spain was spared of the economic meltdown because she chose not to follow incurred base model. He further stated that caution should be exercised in using the international Financial Reporting Standards (IFRS) loan loss provisioning model for internal decision making. Okafor and Okaro (2013) investigating the loan loss provisioning under International Financial Reporting Standards (IFRS) and Nigeria prudential guidelines documented evidence of a huge difference between the two standards and advised that CBN may wish to retain its loan loss provisioning model.

\subsection{Empirical Review}

Brad et al (2010) examined a sample of 150 bank holding companies with large portfolios on non-treasury AFS and HTM securities. They conducted industry and firm level analyses and found firstly, no support for claims that fair value provisions of US accounting rules significantly depleted regulatory capital or caused pro-cyclical selling of securities. That the impact was insignificant to conclude that fair value caused the problem. Secondly, they found no evidence to support the claim that fair value losses caused 'fire-sales of assets'. In Ghana and Zambia, fair value accounting has not been in existence without flaws. Zori (2011) and Mwape (2010) both noted that determination, valuation rules and loan loss instruments are easily manipulated due to inherent assumptions associated with fair value accounting. Ahmed et al (2014) identified that bank manager not only use fair value accounting manage capital requirement, loan loss provisioning is also used in managing both reported earnings and capital, Ahmed et al (1999), Beaty et al (1995) and Ahmed et al (2014) find a positive relationship between loan loss provision and regulatory capital, management exercises discretion over its provision. Akenbor and Ibanichuka (2012) in their study which aimed at empirically investigating creative accounting practices in Nigerian banking industry, using primary data, agreed with Osisoma and Enahoro (2006) who revealed that accounting based, principles and processes should be streamlined in order to reduce diversions of human judgments on accounting issues.

\section{Methodology}

\subsection{Research Design}

This study adopts an ex-post facto research design because the events have taken place and the data are already in existence. Tables, graphs and percentage analyses are used to investigate theoretical and practices of loan loss provisions and measurement of financial instruments in Nigerian banking industry. 


\section{Macrothink \\ International Journal of Accounting and Financial Reporting \\ ISSN 2162-3082 2016, Vol. 6, No. 1}

\subsection{Population for the Study}

The population of the study consists of all the 21 Deposit Money Banks (DMBs) in Nigeria as at $31^{\text {st }}$ December $2015(\mathrm{CBN}, 2015)$. This comprises banks designated as 'too-big-to-fail' or Systematically Important Banks (SIBs) and others (smaller) banks. (www.vanguardngr.com/2014/09/tough-times-ahead-nigeria-bank-investors)

\subsection{Sample and Sampling Technique}

The sample of this study is drawn from listed deposit money banks in the Nigerian Stock Exchange (NSE). The sample consists of 13 banks whose data for the study period 6years, which is 2010 to 2015, are available. I pooled data of 78 banks-year observation of post-IFRS (2010-2015) period, this to enable us carry out both percentage analysis of accounting choices in treating financial instruments as well as their compliance to IFRS rule and CBN prudential guideline on loan loss provisioning. This period, Nigerian banks adopted IFRS and embracing regulators guiding polices. Sample bank inclusion criteria are shown at a glance on appendix 1 which includes:

i) Bank must be in existence on or before 2010-2015

ii) Bank is listed on Nigeria Securities Exchange (NSE)

iii) Bank voluntarily adopted IFRS reporting

iv) Only Deposit Money Banks (DMBs) is included, this to ensure that sample banks face homogenous investment activities and financing methods. (Ozil, 2014)

v) To be included, bank must have complete data up to $30^{\text {th }}$ September or December, 2015, otherwise it is excluded.

The sample from the population was grouped into two based on their assets and equity level as at 2015 financial year. The first group, too-big-to-fail banks (TBTF-banks) (assets >1.5 trillion naira and equity $>230$ billion naira), the second group is smaller banks (S-banks) (assets $<1.5$ trillion and equity $<230$ billion naira). The nature of data for the study will be secondary source. Financial data will be extracted from the published financial statements and reports of the selected studied sample banks. The data for the study will cover a period of 6 years from 2010-2015. 


\section{Macrothink \\ International Journal of Accounting and Financial Reporting \\ ISSN 2162-3082 \\ 2016, Vol. 6, No. 1}

\section{Results and Discussions}

This section of the study examines the results and discussions of relevant findings from the percentages analysis.

\begin{tabular}{|l|l|l|l|lr|l|}
\hline \multirow{2}{*}{ YEAR } & $\begin{array}{l}\text { HELD-TO- } \\
\text { MATURITY } \\
\text { (HTM) } \\
\text { (N'000) }\end{array}$ & $\begin{array}{l}\text { HELD-TO- } \\
\text { TRADING } \\
\text { (HFT) } \\
\text { (N'000) }\end{array}$ & $\begin{array}{l}\text { AVAILABLE- } \\
\text { FOR-SALE } \\
\text { (AFS) } \\
\text { (N'000) }\end{array}$ & $\begin{array}{l}\text { LOAN } \\
\text { ADVANCES } \\
\text { CUSTOMER(LA) } \\
\text { (N'000) }\end{array}$ & $\begin{array}{l}\text { TOTAL } \\
\text { ASSETS } \\
\text { (TA) } \\
\text { (N'000) }\end{array}$ \\
\hline 2010 & $124,240,556.20$ & $29,362,995$ & $68,035,826.60$ & $490,491,899.20$ & $1,416,716,479.0$ \\
2012 & $170,679,372.20$ & $63,894,923$ & $80,620,745.00$ & $820,188,239.80$ & $2,055,339,333.7$ \\
2013 & $140,908,166.20$ & $3,513,724$ & $188,103,614.40$ & $1,016,285,567.00$ & $2,364,535,962.0$ \\
2014 & $73,676,401.60$ & $3,206,509$ & $203,468,830.60$ & $1,292,237,344.40$ & $2,372,422,648.0$ \\
2015 & $81,746,600.00$ & $8,909,923$ & $170,302,168.60$ & $1,350,237,950.40$ & $2,821,269,857.0$ \\
\hline
\end{tabular}

Table 2 Figures and Averages of Six Years Summary of Held-to-Maturity, Held-forTrading, Available-for-Sale Financial Instruments and Total Assets Obtained From the Five (5) Too-Big-To-Fail Banks of Study Sample

Sources: Computation from Published Annual Reports and Financial Statements (2010-2015) 


\begin{tabular}{|c|c|c|c|c|c|}
\hline YEAR & $\begin{array}{l}\text { HELD-TO- } \\
\text { MATURITY } \\
\text { (HTM) } \\
\text { (N'000) }\end{array}$ & $\begin{array}{l}\text { HELD-TO- } \\
\text { TRADING } \\
\text { (HFT) } \\
\left(\mathrm{N}^{\prime} 000\right)\end{array}$ & $\begin{array}{l}\text { AVAILABLE- } \\
\text { FOR-SALE } \\
\text { (AFS) } \\
\left(\mathrm{N}^{\prime} 000\right)\end{array}$ & $\begin{array}{lr}\text { LOAN } & \text { AND } \\
\text { ADVANCES } & \text { TO } \\
\text { CUSTOMER(LAC) } \\
\left(\mathrm{N}^{\prime} 000\right)\end{array}$ & $\begin{array}{l}\text { TOTAL } \\
\text { ASSETS } \\
\text { (TA) } \\
\left(N^{\prime} 000\right)\end{array}$ \\
\hline 2010 & $13,395,845.50$ & $991,260.00$ & $11,822,246.38$ & $163,512,564.25$ & $395,674,799.34$ \\
\hline 2011 & $44,132,113.75$ & $15,994,951.25$ & $68,826,015.38$ & $220,146,851.25$ & $626,542,812.75$ \\
\hline 2012 & $52,848,718.63$ & $53,947,262.00$ & $53,008,542.38$ & $292,019,819.38$ & $758,425,121.63$ \\
\hline 2013 & $99,418,342,99$ & $40,247,230.25$ & $37,398,344.75$ & $346,750,268.50$ & $868,306,852.13$ \\
\hline 2014 & $57,288,612.63$ & $11,448,432.38$ & $59,159,276.88$ & $622,593,870.38$ & $802,809,284.00$ \\
\hline 2015 & $28,262,612.50$ & $1,095,329.50$ & $104,030,485.75$ & $538,140,302.13$ & $553,384,466.38$ \\
\hline
\end{tabular}

Table 3: Figures and Averages of Six Years Summary of Held-to-Maturity, Held-forTrading, Available-for-Sale Financial Instruments and Total Assets Obtained From the Eight (8) of Smaller Banks of Study Sample

Sources: Computation from Published Annual Reports and Financial Statements (2010-2015)

\begin{tabular}{|c|c|c|}
\hline & $\begin{array}{l}\text { Too-Big-To-Fail Banks } \\
\text { (Assets }>1.5 \text { Trillion Naira) } \\
\text { (Equity >230 Billion Naira) }\end{array}$ & $\begin{array}{l}\text { Smaller Banks } \\
\text { (Assets < } 1.5 \text { Trillion Naira) } \\
\text { (Equity < } 230 \text { Billion Naira) }\end{array}$ \\
\hline Held-For-Trading (HFT) & $1.07 \%$ & $3.09 \%$ \\
\hline Available-For-Sale (AFS) & $6.09 \%$ & $8.35 \%$ \\
\hline Held-To- Maturity (HTM) & $6.65 \%$ & $7.37 \%$ \\
\hline $\begin{array}{l}\text { Loan and Advances to } \\
\text { Customers (LAC) }\end{array}$ & $43.99 \%$ & $54.51 \%$ \\
\hline Total:(HFT+AFS+HTM+LAC) & $57.80 \%$ & $73.32 \%$ \\
\hline Total Assets (TA) & $100 \%$ & $100 \%$ \\
\hline
\end{tabular}




\section{Macrothink \\ International Journal of Accounting and Financial Reporting \\ ISSN 2162-3082 \\ 2016, Vol. 6, No. 1}

Table 4: KEY ASSETS ON STATEMENT OF FINANCIAL POSITIONS (BALANCE SHEETS) OF NIGERIA BANKS (as a fraction of total assets for the years 2010-2015)

Source: Computation from Tables 2 and 3

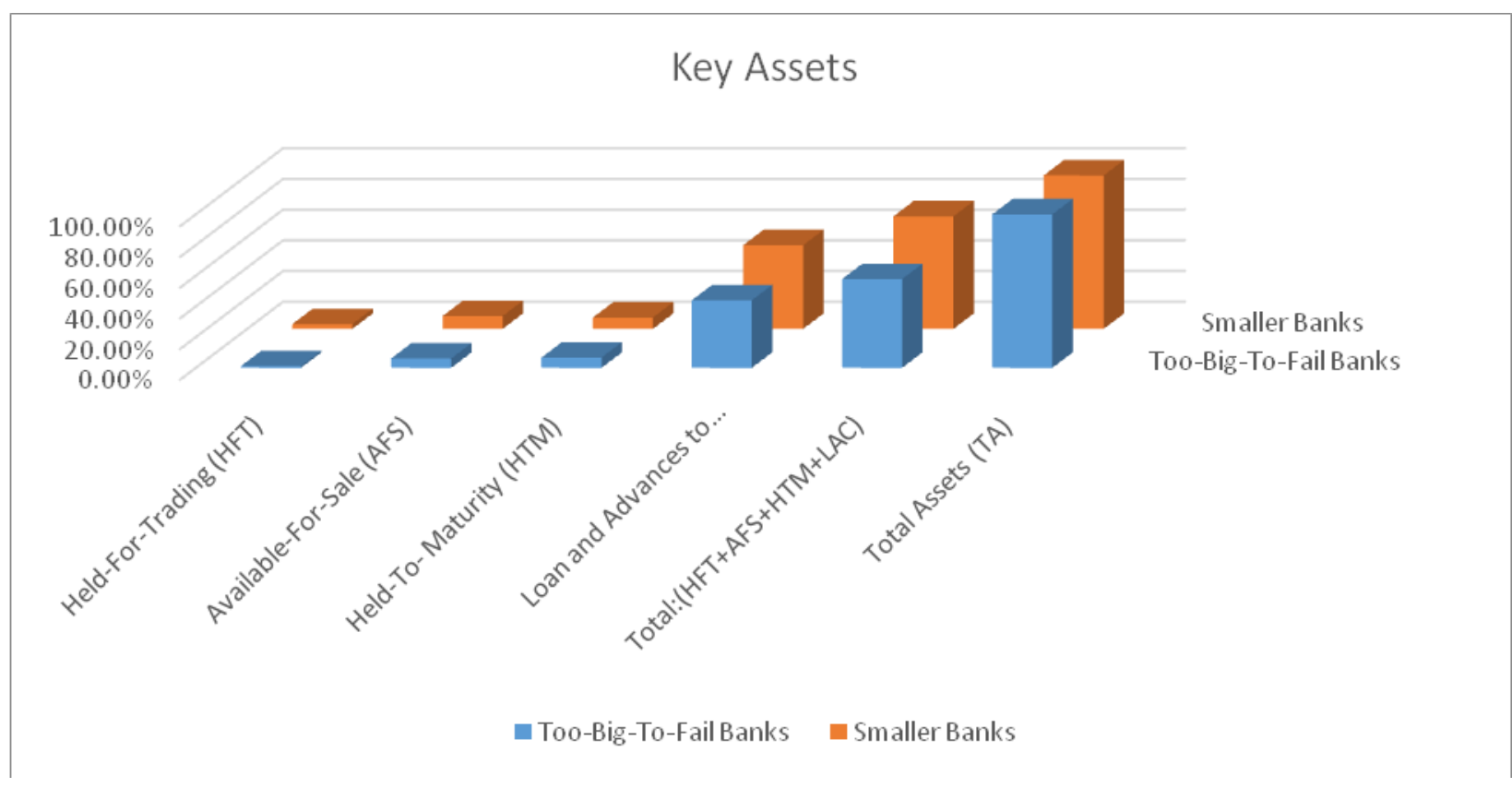

Note the table reports and figure 2 (weighted) averages over the year end amounts from 2010-2015 for various bank assets listed above within each group and year observations are weighted by total assets. Table 4 provides assets averages for the key assets of Nigeria banks reported values as a fraction of total assets for the years 2010 to 2015. In doing this analysis, we distinguished between large bank otherwise called too-big-to-fail banks and smaller banks as they exist in post IFRS period. The larger banks (Too-big-to-fail banks) include banks with total assets greater than N1.5 trillion and equity greater than N230 billion. Smaller banks include banks with assets less than N1.5 trillion and equity less than N230 billion. The subsequent discussion in the next section of the study describes the categories of assets in tables above along with accounting theories and practices.

\begin{tabular}{|l|l|l|l|l|l|l|}
\hline BANK & YEAR & $\begin{array}{l}\text { CBN- } \\
\text { ELLM (1) }\end{array}$ & $\begin{array}{l}\text { IFRS- } \\
\text { ILLM (2) }\end{array}$ & $\begin{array}{l}\text { D } \\
(\mathbf{1})-(2)=3\end{array}$ & $\begin{array}{l}\text { TIER 1 } \\
\text { CAPITAL }\end{array}$ & $\begin{array}{l}\text { D AS \% } \\
\text { OF } \\
\text { TIER1 } \\
\text { CAPITAL }\end{array}$ \\
\hline & 2012 & $37,369,723$ & $33,249,429$ & $4,000,000$ & $189,823,586$ & 2.12 \\
ACCESS & 2013 & $24,874,774$ & $13,249,429$ & $11,625,429$ & $188,248,156$ & 6.18 \\
& 2014 & $34,014,459$ & $17,012,478$ & $17,001,981$ & $264,026,949$ & 6.45
\end{tabular}




\begin{tabular}{|c|c|c|c|c|c|c|}
\hline & 2015 & $64,741,551$ & $26,915,169$ & $37,826,382$ & $346,610,579$ & 10.91 \\
\hline \multirow{4}{*}{ FBN } & 2012 & $59,303,000$ & $43,202,000$ & $16,101,000$ & $356,772,000$ & 4.50 \\
\hline & 2013 & $50,168,000$ & $42,650,000$ & $7,518,000$ & $352,011,000$ & 2.13 \\
\hline & 2014 & $83,724,000$ & $38,867,000$ & $38,724,000$ & $316,687,000$ & 12.20 \\
\hline & 2015 & & & & & \\
\hline \multirow{4}{*}{ GTB } & 2012 & $28,133,141$ & $16,820,339$ & $11,312,802$ & $279,885,158$ & 4.04 \\
\hline & 2013 & $36,834,283$ & $19,999,560$ & $16,834,723$ & $318,112,889$ & 5.29 \\
\hline & 2014 & $36,834,000$ & $19,999,560$ & $16,900,396$ & $301,037,314$ & 5.61 \\
\hline & 2015 & $78,324,985$ & $26,309,048$ & $52,309,048$ & $374,059,393$ & 13.98 \\
\hline \multirow{4}{*}{ UBA } & 2012 & $9,882,000$ & $8,769,000$ & $1,113,000$ & $137,756,000$ & 0.81 \\
\hline & 2013 & $12,787,000$ & $8,374,000$ & $4,413,000$ & $166,938,000$ & 2.64 \\
\hline & 2014 & $15,859,000$ & $10,653,000$ & $5,206,000$ & $252,861,000$ & 2.05 \\
\hline & 2015 & $31,364,000$ & $14,104,000$ & $17,260,000$ & $288,986,000$ & 5.97 \\
\hline \multirow{4}{*}{ ZENITH } & 2012 & $21,437,000$ & $15,768,000$ & $5,669,000$ & $434,750,000$ & 1.33 \\
\hline & 2013 & $37,252,000$ & $27,678,000$ & $9,574,000$ & $467,402,000$ & 2.05 \\
\hline & 2014 & $40,878,000$ & $31,190,000$ & $9,686,000$ & $496,398,000$ & 1.95 \\
\hline & 2015 & $63,258,000$ & $41,908,000$ & $21,350,000$ & $521,282,000$ & 4.09 \\
\hline
\end{tabular}

Table 5

LOAN LOSS PROVISIONING UNDER CBN PRUDENTIAL (EXPECTED LOSS MODEL) AND IFRS INCURRED MODEL FOR FIVE (5) TOO-BIG- TO-FAIL BANKS: 2012-2015

Sources: Computation from Published Annual Reports and Financial Statements (2010-2015) 


\begin{tabular}{|c|c|c|c|c|c|c|}
\hline BANK & YEAR & $\begin{array}{l}\text { CBN-ELLM } \\
\text { (1) }\end{array}$ & $\begin{array}{l}\text { IFRS- } \\
\text { ILLM (2) }\end{array}$ & $\begin{array}{l}\text { D } \\
(1)-(2)=3\end{array}$ & $\begin{array}{l}\text { TIER } 1 \\
\text { CAPITAL }\end{array}$ & $\begin{array}{l}\text { D AS \% } \\
\text { OF } \\
\text { TIER1 } \\
\text { CAPITA } \\
\text { L }\end{array}$ \\
\hline \multirow{4}{*}{ DIAMOND } & 2012 & $28,063,369$ & $31,628,761$ & $-3,565,392$ & $91,570,839$ & -3.89 \\
\hline & 2013 & $27,175,347$ & $28,152,031$ & $-976,684$ & $133,455,135$ & -0.73 \\
\hline & 2014 & $34,849,175$ & $39,597,655$ & $-4,748,480$ & $189,862,887$ & -2.50 \\
\hline & 2015 & & & & & \\
\hline \multirow{4}{*}{ FIDELITY } & 2012 & $19,224,000$ & $20,012,000$ & $-788,000$ & $161,744,000$ & -0.49 \\
\hline & 2013 & $21,844,000$ & $22,567,000$ & $-723,000$ & $163,380,000$ & -0.44 \\
\hline & 2014 & $25,551,000$ & $20,471,000$ & $5,066,000$ & $143,955,000$ & 3.52 \\
\hline & 2015 & $32,640,000$ & $23,110,000$ & $9,530,000$ & $143,696,000$ & 6.62 \\
\hline \multirow{4}{*}{ UBN } & 2012 & $193,483,000$ & $192,478,000$ & $1,005,000$ & $32,949,000$ & 3.05 \\
\hline & 2013 & $216,203,000$ & $212,497,000$ & $3,706,000$ & $48,056,000$ & 7.71 \\
\hline & 2014 & $221,560,000$ & $212,893,000$ & $8,667,000$ & $67,962,000$ & 12.75 \\
\hline & 2015 & $58,423,000$ & $34,547,000$ & $23,876,000$ & $70,075,000$ & 34.07 \\
\hline \multirow{5}{*}{ STANBIC } & 2012 & $18,421,000$ & $18,421,000$ & 0 & $59,148,000$ & 0.00 \\
\hline & 2013 & $17,982,000$ & $17,213,000$ & 769,000 & $63,130,000$ & 1.29 \\
\hline & 2014 & $23,635,000$ & $20,269,000$ & $3,366,000$ & $62,356,000$ & 5.90 \\
\hline & 2015 & & & & $71,021,000$ & \\
\hline & 2012 & $14,250,574$ & $13,434,210$ & 816,364 & $17,880,640$ & 4.57 \\
\hline WEMA & 2013 & $7,694,414$ & $7,724,779$ & $-30,365$ & $18,025,449$ & -0.17 \\
\hline
\end{tabular}




\begin{tabular}{|c|c|c|c|c|c|c|}
\hline & 2014 & $8,184,297$ & $7,393,091$ & 791,206 & $20,006,689$ & 3.95 \\
\hline & 2015 & $9,739,684$ & $6,095,642$ & $3,644,042$ & $19,330,694$ & 18.85 \\
\hline \multirow[t]{4}{*}{ STERLING } & 2012 & $11,811,635$ & $11,752,908$ & 58,727 & $38,832,849$ & 0.15 \\
\hline & 2013 & $13,889,373$ & $12,945,690$ & 943,684 & $56,181,292$ & 1.68 \\
\hline & 2014 & $18,603,154$ & $14,722,416$ & $3,880,738$ & $81,370,755$ & 4.77 \\
\hline & 2015 & $22,387,216$ & $17,317,201$ & $5,070,015$ & $73,295,247$ & 6.91 \\
\hline \multirow[t]{4}{*}{ UNITY } & 2012 & $21,482,800$ & $21,360,711$ & 122,090 & $(21,633,995)$ & -0.56 \\
\hline & 2013 & $91,518,169$ & $62,878,170$ & $28,640,000$ & $41,241,029$ & 69.28 \\
\hline & 2014 & $85,189,365$ & $46,788,851$ & $38,400,508$ & $4,453,289$ & 862.29 \\
\hline & 2015 & & & & & \\
\hline
\end{tabular}

Table 6

LOAN LOSS PROVISIONING UNDER CBN PRUDENTIAL (EXPECTED LOSS MODEL) AND IFRS INCURRED MODEL FOR FIVE (6) SMALLER BANKS: 2012-2015

Source: Computation from Published Annual Reports and Financial Statements 


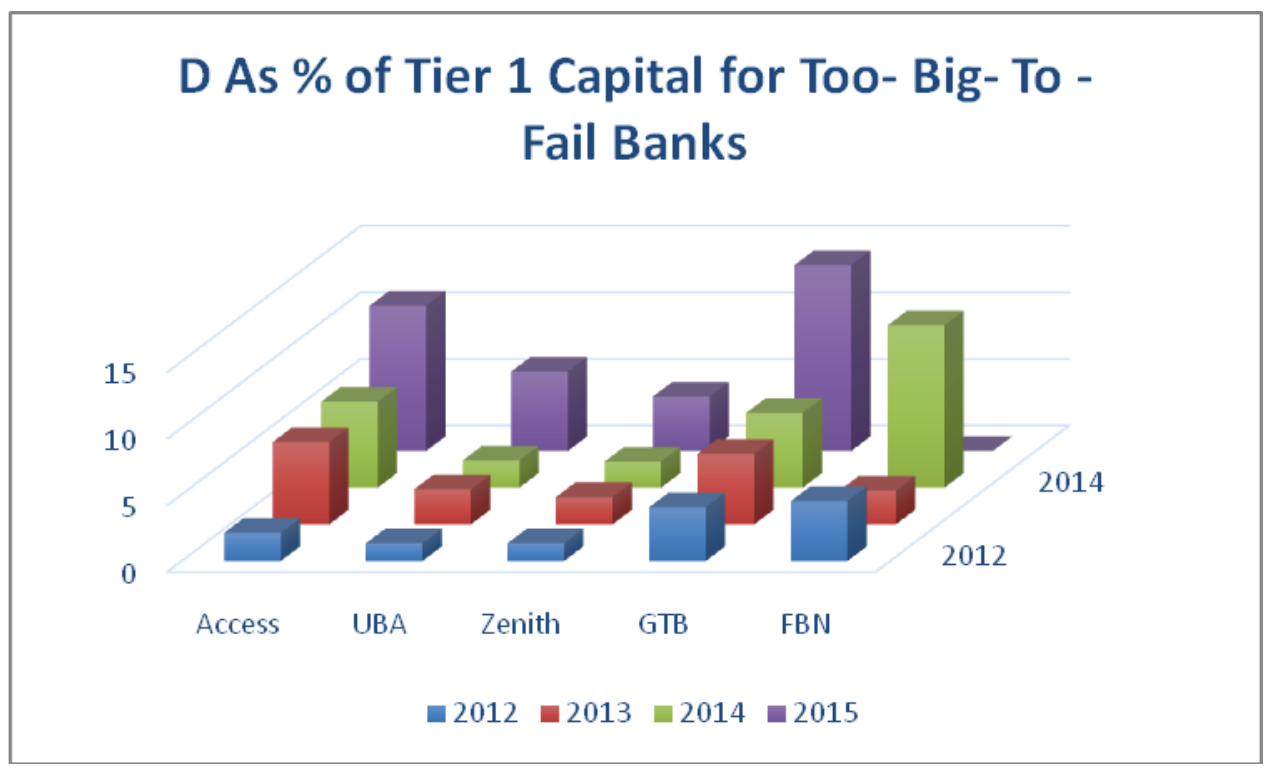

Source: Table 5

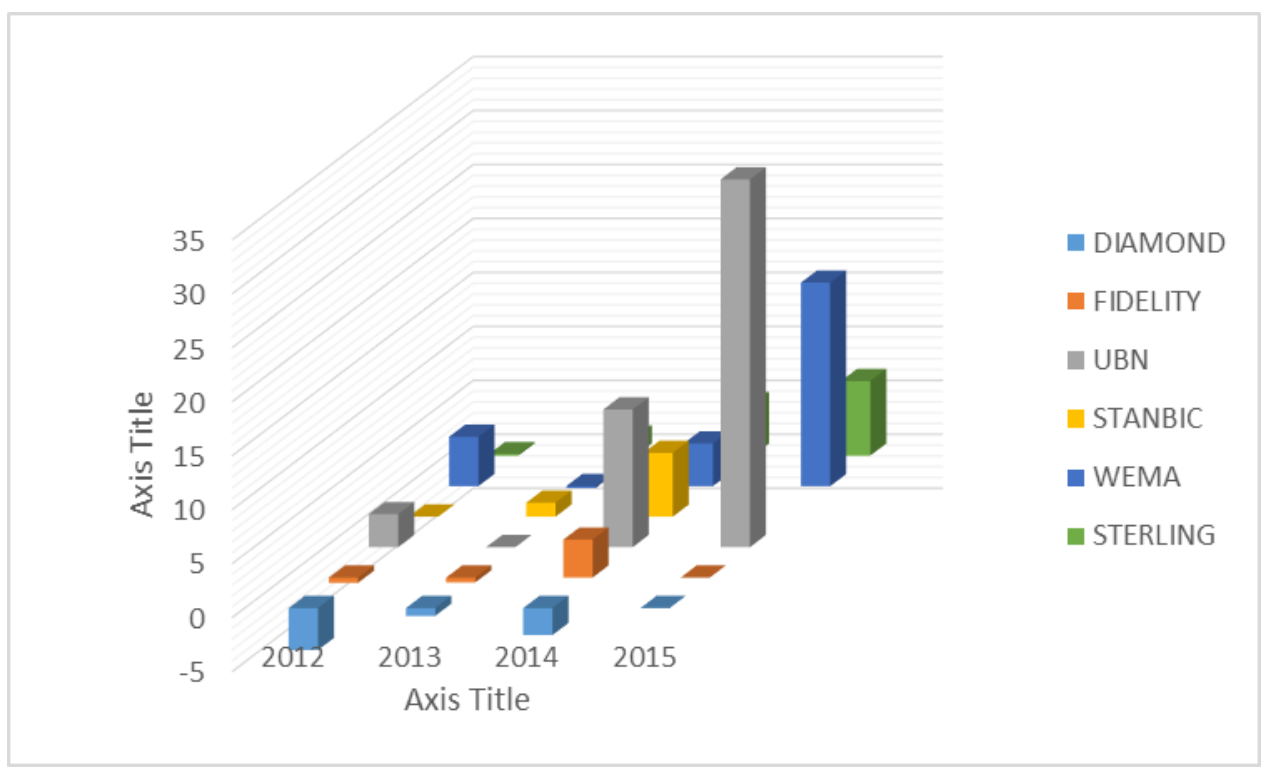

Source: Table 6

\section{Discussion of Findings}

Loan and advances is by far the most important asset for banks and generally account for almost half of banks' total assets (Laux and Lenz, 2010). From table 4, loans and advances accounted for $43.99 \%$ for total assets of Too-Big-To-Fail banks (TBTF-Banks) while $54.51 \%$ of total assets of Smaller banks (S-banks) was accounted by loans and advances. They can be classified as either 'held -for- investment' or 'held-for-sale'. Held- for-sale loans and advances are carried at the lower of historical cost or fair value. In practice it is noted that the fraction of loans and lease in this category is typically very small (see figure 2 and table 3 ). On the other hand, held -for- investment loans and advances historical (original) cost applies. 


\section{Mll Macrothink}

International Journal of Accounting and Financial Reporting ISSN 2162-3082 2016, Vol. 6, No. 1

They are carried at principal amount outstanding adjusted for amortization and are subject to weak impairment testing (FASB, 2006). According to FAS 115, 'held-for-trading' financial instruments are bought and held principally for the purpose of selling them in the near term. Here, fair value accounting applies and fair value changes are recognized in the income statement. For both TBTF-Banks and S-Banks in Nigeria, trading assets constitute an unimportant fraction, $1.07 \%$ and $3.09 \%$ respectively. This finding is in line with Laux and Lenz (2010) about US banks.

For too -big- to fail banks, "other securities" that are not held for trading and that are classified either as held - to- maturity or available-for-sale are not substantially part of the balance sheet. They are $6.09 \%$ and $6.65 \%$ respectively. In this category available - for - sale securities are carried at fair value. Unrealized gains and losses arising from changes in fair value that are view temporary are not recognized in the income statement, but in a separate component of shareholder's equity called accumulated other comprehensive income. However, if such changes are deemed "other-than-temporary", then asset has to be writtendown to its fair value and loss is recognized in the income statement. This is also applicable to smaller banks which have $8.35 \%$ and $7.37 \%$ for available -for - sale and held-to -maturity. Held- to -maturity investment in debts securities that banks have internet and ability to hold until they mature are carried in balance sheet at historical cost adjusted for amortization. Subject to impairment testing and banks have to disclose their aggregate fair value in the notes to the financial statements. Both classes of Nigeria banks follows mixed attribute accounting rule in carrying their financial instruments to balance sheet.

Further investigation on loan loss provision post- IFRS period, we noticed that CBN like other regulators of financial institutions in Nigeria emphasize increased bank loan loss provisioning while the IFRS tend to discourage aggressive provisioning for transparency concerns. This is consistent with theory. Wall and Koch (2008) in their study X-ray three different philosophies on loan loss accounting. among are FASB's view that is the measurement of a firm's net income over a given period and the capital view sees loan loss allowance as an element of capital. From the analysis, the difference between CBN prudential loan loss provision and IFRS incurred loan loss provision as a percentage of tier 1 capital for Too-big-to fail banks is high compare to smaller banks.

\section{Summary, Conclusion and Recomendati0ns}

The problems identified in the cause of reviewing other scholars work were stated. Among these problems are "legal manipulation of figures" through accounting choices by bank managers and accountants, that investors and taxpayers suffer the negative effects of this false financial statement been cooked up and lack of common view between bank regulators and accounting standard setters on how loan loss allowance should be provided.

From the study, we observed that both the too-big-to fail and smaller banks in Nigeria like their counterparts in other countries use mixed attribute accounting (MAA) which is partly fair value method and historical cost method of accounting.

We also documented evidence in this study that too-big -to fail banks are more aggressive in 
the loan loss provisioning based on CBN Prudential guideline unlike smaller banks.

\subsection{Conclusions}

Owing to the study which examined accounting theories and practice as they relate to loan loss provisioning and measurement of financial instruments by listed banks in Nigeria, the researcher had cause to come to certain conclusions as follows:

Consistent with Healy and Wahlen (1999) and Ozili (2014), it is important for regulators to understand the impact of discretionary loan loss accounting used by both managers and accountants to influence the bank capital and earnings.

The study provided evidence that money deposit banks in Nigeria use loan loss provision to manage capital. This is the second evidence in Nigeria context.

Based on our finding, we also conclude that bank size does not influence the relationship between loan loss provisioning and capital management.

The study grouped the sample banks into two, the too-big-to fail banks and smaller banks to empirically investigate the difference between the loan loss provisioning under IFRS and the CBN prudential guideline. The differences were expressed as percentage of their respective individual banks tier I capital within the two groups and TBTF-Banks were positive provisioning than that of S-Banks that recorded more of negative provisioning. This implies higher conservatism for too-big-to fail banks and lesser conservatism for smaller banks as regards to loan loss accounting. This suggests that regulators emphasize on increased bank provisioning while the IFRS tend to discourage aggressive provisioning for transparency concerns. It should be recalled that $\mathrm{CBN}$ introduced this prudential provisioning because of the apparent abuse of loan loss provision in the banking sector. It also implies instead of using to create a false profit report or declare high dividend (earning management or signaling) the difference is being credited to a regulatory reserve which is part of tier 1 capital. Finally we conclude that Nigeria banks cannot claim that fair value accounting is destroying its balance sheet as its been claimed by banks in other countries. This conclusion is based on their choices of categorizing their financial instruments either as held-to- maturity (HTM) or available -for-sale (AFS) and held-for-trading (HFT). What we observed in their various balance sheets reported in line with IFRS is a mixed attribute accounting (MAA).

\subsection{Recommendations}

Based on the findings and conclusions, the following recommendations are made:

Lending voice to Osisioma and Enahoro (2006) and Akenbor and Ibanichuka (2012) we recommend that accounting principles and rules should be streamlined to reduce diversities of professional judgment in financial reporting. There should be synergy between the regulators and accounting standard setters (CBN and IASB). The stability of the financial system and providing the honest and true information to investors should be a paramount objective of the two bodies. Nigerian banks should quickly adopt IFRS 9 model of loan loss provision that agrees with $\mathrm{CBN}$ expected loan loss provisioning. 


\section{Macrothink \\ International Journal of Accounting and Financial Reporting \\ ISSN 2162-3082 \\ 2016, Vol. 6, No. 1}

\subsection{Contribution to Knowledge}

Despite the limitations of this study it has provided a number of insights and contributions to the current literature and concerns of accounting standard setters and bank regulators on the current model of loan loss provision as well as on-going debate that fair value accounting destroys banks' balance sheets. It also provide evidence that Too-big-to fail banks unlike smaller banks increased loan loss provisioning in line with regulators emphasize on aggressive provisioning. This provide evidence that regulators are forward looking and emphasize on increased provisioning while the IFRS is backward looking and tend to discourage aggressive provisioning. The study provides evidence that the assumption of pure fair value accounting (PFVA) does not exist among Nigeria banks rather mixed attribute accounting (MAA) model.

\section{Reference}

Ahmed, S.A, Takeda, C, Thomas, S.E (1999) "Bank Loan Loss Provisions: A Reexamination of Capital

Management, Earnings Management and Signaling Effects. Journal of Accounting and Economics, vol. 28, No.1

Ahmed, A. Abdu, Y.M and Abdulmarooph, D.A (2014) Loan Loss Provision and Earnings Management in

Nigeria Deposit Money Banks. Mediterranean Journal of Social Sciences. Vol.5 No.17 July.

Akenbor, C.O and Ibanichuka, E.A. L (2012) "Creative Accounting Practices in Nigerian Banks"

African Practices in Nigerian Banks" African Research Review, Vol. 6 (3) Serial No. 26

Allen, F. And E. Carletti (2008) Mark-to-Market Accounting and Liquidity Pricing. Journal of Accounting and Economics 45: 358 - 378

Anandarayan, A. Hassan, I and McCarthy, C. (2004) The Use of Loan Loss Provision for Capital Management and Signaling by Australian Banks. Finland Discussion Papers, Payer 23(2006).

Andrew, B (2014) The capital adequacy of banks: today's issues and what we have learned from the past.

Prudential Regulatory Authority, Bank of England. Available online www.bankofEngland.co.uk/publications/pages/speeches/default.aspx

Angahar, A. P (2012) “An Evaluation of the Regulatory Framework for the Prevention of Misstatement of 


\section{MInstitute Macrothink $_{\text {Int }}$}

International Journal of Accounting and Financial Reporting ISSN 2162-3082

Financial Statement in Nigeria: Global Advanced Research Journal of Management and Business Studies Vol. 1(x) pp.051 - 060.

Bala, A and Hope M. (2014) "FRC sees fair value accounting enhancing financial Statement reliability" Businessday, December, 15

Beathy, A and Liao, S. (2009) "Regulatory Capital Ratios, Loan Loss Provisioning and PreCyclicality" Working Paper, the Ohio State.

Beathy, A.; Chamberlin. S. L, and Magliolo, S (1995) "Managing Financial Reports of Commercial Banks: The Influence of Taxes, Regulatory Capital, and Earnings. Journal of Accounting Research 33: 231 - 261.

Benston, G and L. Wall (2005) "How should banks accounting for loan losses?" Economic Review 19-3

Blaanw, A (2009) Dynamic Provisioning and IFRS Adoption by Nigerian Banks. UBA pp 1-3

Brad, A.B Jeffery, I. Peter, D.E (2010) A Convenient Scapegoat: Fair Value Accounting by Commercial Banks during the Financial Crisis.

CBN, (2013) CBN Guidance notes on the calculation of regulatory capital. Available online.

www.cbnbank.org/out/2013/BSD/2 Guidance $\% 20$

Cifuentes, R. H. Shine, and Ferrucci, G (2005). Liquidity Risk and Contagion. Journal of the European Economics Association 3: 556 - 566.

Collins,I, Shackelford, D and Wahlen, J (1995) Bank Difference in the Coordination of Regulatory Capital, Earning and Taxes. Journal of Accounting Research, 33: 263 - 292.

Curcio, D. and Hasan, I (2013) Earnings and Capital Management and Signaling: The Use of Loan - Loss Provisions by European Banks, The European Journal of Finance. 1 - 25.

Doro, N and Stephen. P (2008) Principles for the Application of Fair Value Accounting. The Center for Excellence in Accounting and Security Analysis White Paper Number Two.

Elmeraji, J (2008) Mark-to-Market Mayhem. Available online.http://www.investopedia.com/articles/financial-theory/08/mark-to-market-mayhem.asp Enahoro, J.A and Jayeoba. J (2013) "Value Accounting" Asian Economic and Financial Review, 2013, 3(9): 1170 - 1197.

Ezejelue, A.C (2004) Accounting Problems of Less Developed Countries. Inaugural Lecture, Abia State University, Uturu June 29.

Financial Accounting Standards Board (FASB) (2006), Preliminary view: Conceptual Framework for Financial Reporting: objective of Financial Reporting and Qualitative Characteristics of Decision useful financial reporting information. Financial series No. 1260001. July 6. Norwalk, CT: FASB.

Garcia-Feijoo, L (2009) "Financial briefing: Fair Value Accounting rules. The Financial 


\section{Al Macrothink}

International Journal of Accounting and Financial Reporting

ISSN 2162-3082

2016, Vol. 6, No. 1

Times. Available online. www.ft.com/cms/s/o/72dbaa6-4dc9-11 de-a0a1-00.

Glautier, M., Underdown, M. and Morris D. (2011) Accounting Theory and Practice. $8^{\text {th }}$ Edition Financial Times Practice Hall

ICAEW Financial Reporting Faculty (2010) Business Models in Accounting: the theory of the firm and financial reporting information for better markets initiative. Icaew.com/frf

Kambayashi, S (2008) The crisis and fair-value accounting. Available online:

http://www.economist.com/node/1227409

Katudu, A. S (2008) Impact of Nigerian Accounting Standard Board Act 2005 on Compliance with Accounting Standard on Employees' Retirement Benefits in Nigeria. Accounting Department, Bayero University Kano Social Science Electronic Publishing. Available Online: http://www.ssrn.com.

Kerr, G (2013) “Europe’s Accounting Rules and Destroying Its Banks” Available Online http://www.cobdencentre.org/author/gordon/

Kieso. D. E., Jerry. J. W., Terry D. W., Nicola M.Y and Irene. M. W (2010) Intermediate Accounting. John Wiley \& Sons Canada Ltd. Volume 1. P.39

Kirsten G (2012) "The lost Bank: The story of Washington Mutual- The Biggest Bank failure in American History" Available online: http://www.cnbc-com/id/

Lanx, C and C. Lenz (2009) "The Crisis of Fair Value Accounting: Making Sense of the Recent Debate" Accounting, Organizations and Society, 34(6-7) :826-34.

Lanx, C and Lenz. C (2010) "Did Fair-Value Contribute to the Financial Crisis? The Journal of Economic Perspective, Vol. 24, No. 1, pp 93 - 118.

Leventis, S., Dimitropoulos, P. E and Anandarajan, A (2011) "Loan Loss Provisions, Earnings Management andCapital Management Under IFRS: The Case of EU Commercial Banks". Journal of Financial Services Research, 40(1): 103 - 122.

Leventis, S. Dimitropoulos, P.E and Anandarajan, A (2012), "Signaling by Banks Using Loan Loss Provisions: The Case of the European Union" Journal of Economic Studies, 39(5): 604 $-618$.

Lionel, E., Foulquier, P. and Touron, P (2008) The Fair Value Controversy: Ignoring the Real Issue EDHEC Business School.

Liu, C., Ryan, S.G, Wahlem, J.M (1997) "Differential Valuation Implications of Loan Loss Provision across Banks and Fiscal Quarters”. The Accounting Reviews, 72: (1) 133 - 146.

Liu, C and Ryan, S. G (2006) "Income Smoothing on the Business Cycle: Changes in Banks Coordinated Management of Provisioning for Loan Losses and Loan Charge-offs from the pre-1990 Bust to the 1990s Boom” The Accounting Review. Vol.81, No. 2: pp. $421-441$.

Moyer, S.E (1990) Capital Adequacy Ratio Regulations and Accounting Choices in 


\section{MInstitute ${ }^{\text {Macrothink }}$}

International Journal of Accounting and Financial Reporting

ISSN 2162-3082

Commercial Banks. Journal of Accounting and Economics, (13): 123 - 154.

Mwape, A.K (2010) Lessons Learnt from Implementing IFRS: A Regulator Perspective CBN Conference Proceedings.

Norden, L and Stoian, Anamawa (2013) Bank earnings management through loan loss provisions. A double-edged sword? DNB working paper No. 404/December

Okafor, C.O. and Okaro, G.O (2013) Fair Value Accounting and Loan Loss Provisioning Early Evidence from Nigerian Banking Industry. Research Journal of Finance and Accounting. Vol.4, No.8.

Okafor, C and K.O Ogiedu, (2012) Perceptions of Fair Value Accounting: Evidence from Nigeria. JORIND 10(3).

Osisioma, B. C. and Enahoro, J. A. (2006). "Creative Accounting and Option of Total Quality Accounting in Nigeria"; Journal of Global Accounting.2(1); 5-15,

Oxford Dictionary of Accounting (2005) A Dictionary of Accounting.3rd Edition Oxford University Press

Otusanya, M.O (2012) Zenith Bank Plc and Subsidiary Companies Consolidated and Separated Financial Statements for the year ended 31st December. Lagos.

Ozili, K.P (2014) Loan Loss Provisioning, Income Smoothing, Signaling, Capital Management and Procyclicality: Does IFRS Matter? Empirical Evidence from Nigeria Essex Business School, University of Essex, UK.

Plantin, G., Sapra, H and H. Shin (2008) Marking-to-Market Panacea or Pandora's Box? Journal of Accounting Research 46: 435 - 460.

Ramana, K (2008) The implications of unverifiable fair-value accounting:Evidence from the political economy of good will accounting, Journal of Accounting and Economics 45:253-281

Remana, K. and Watt, R.L (2009) "Evidence from Goodwill Non-Impairment on the Effects of Using Unverifiable Estimates in Financial Reporting”Harvard Business Accounting Management Unit Working Paper 0-106. Harvard Business School.

Ryan S.G (2008) "Accounting in and for the subprime crisis" Available at ssrn http://ssm.com/abstract=1115323.

Scholes, M. Wilson, G. P. Wolfson, M.(1990) “Tax Planning, Regulatory Capital Planning and Financial Reporting Strategy for Commercial Banks Rev. Finance Studies 3: 625- 650.

Shaffer, S (2011) Evaluating the Impact of Fair Value Accounting on Financial Institution: Implications for Accounting Standards. Federal Reserve Bank of Boston QAU WPs No. 2012 -01 .

UBA (2012) Annual Report 2012

Wall, L.D and Kochi, T.W (2000) The Use of Accruals to Manage Reported Earnings: Theory 


\section{Macrothink \\ International Journal of Accounting and Financial Reporting \\ ISSN 2162-3082}

and Evidence Working Paper Series, Federal

Yonetani, T and Katsue, Y (1998) "Fair Value Accounting and Regulatory Capital Requirement” FRBNY Economic Policy Review. October.

Zori, George, S. (2011) IFRS in the African Continent: A Look at Ghana. AfricanNews.com.

www.investopedia/articles/stocks/enron-collapse.asp

www.proshareng.com/news/16728

www.enownow.com/news/story/php?sno=8606

http://fic.wharton.upenn.edu/fic/papers/11/11-72.pdf

www.africanfinancials.com/Company_list.aspx?countryUID=11 


\section{Macrothink \\ International Journal of Accounting and Financial Reporting ISSN 2162-3082}

Appendix I

SHOWING THE NUMBER OF BANKS AND CRITERIA FOR INCLUSION IN THE SAMPLE

\begin{tabular}{|c|c|c|c|c|c|c|}
\hline $\mathbf{S} / \mathbf{N}$ & Bank & $\begin{array}{c}\text { Year of } \\
\text { Incorporation }\end{array}$ & $\begin{array}{l}\text { Year of } \\
\text { Listing }\end{array}$ & $\begin{array}{l}\text { Evidence } \\
\text { of IFRS }\end{array}$ & $\begin{array}{c}\text { Evidence } \\
\text { of Tier } 1 \& \\
\text { Tier II }\end{array}$ & $\begin{array}{c}\text { Data } \\
\text { Complete }\end{array}$ \\
\hline 1. & Access Bank Plc & 1989 & 1998 & Yes & yes & YES \\
\hline 2. & Diamond Bank Plc & 1990 & 2005 & Yes & yes & YES \\
\hline 3. & Eco Bank Plc & 1985 & 2003 & Yes & yes & YES \\
\hline 4. & Fidelity Bank & 1988 & 2005 & Yes & yes & YES \\
\hline 5. & First Bank of Nig. Plc & 1894 & 1971 & Yes & ye & YES \\
\hline 6. & First City Monument Bank & 1982 & 2004 & Yes & yes & $\mathrm{NO}$ \\
\hline 7. & Guaranty Trust Bank Plc & 1990 & 1996 & Yes & yes & YES \\
\hline 8. & $\begin{array}{l}\text { Nigeria Police Force } \\
\text { (NPF) Micro. Finance }\end{array}$ & 1993 & 2010 & Yes & yes & NO \\
\hline 9. & Skye Bank Plc & 1989 & 2006 & Yes & yes & NO \\
\hline 10. & Stanbic IBTC Plc & 2000 & 2007 & Yes & yes & YES \\
\hline 11. & Sterling Bank Plc & 1960 & 2006 & Yes & yes & YES \\
\hline 12. & Standard Chartered Bank & & & Yes & yes & NO \\
\hline 13. & Union Bank Plc & 1917 & 1971 & Yes & yes & YES \\
\hline 14. & Unity Bank Plc & 2006 & 2006 & Yes & yes & YES \\
\hline 15. & UBA Plc & 1948 & 1971 & Yes & yes & YES \\
\hline 16. & Wema Bank Plc & 1945 & 1990 & Yes & ys & YES \\
\hline 17. & Zenith Bank Plc & 1990 & 2004 & Yes & yes & 'YES \\
\hline
\end{tabular}




\begin{tabular}{|c|c|c|c|c|c|c|}
\hline \multirow[b]{2}{*}{18.} & $\begin{array}{l}\text { Macrothink } \\
\text { institute }\end{array}$ & \multicolumn{5}{|c|}{$\begin{array}{r}\text { International Journal of Accounting and Financial Reporting } \\
\text { ISSN 2162-3082 } \\
2016, \text { Vol. 6, No. } 1\end{array}$} \\
\hline & $\begin{array}{l}\text { Enterprise Bank Limited } \\
\qquad(\mathrm{EBL})\end{array}$ & 2011 & NL & Yes & yes & $\mathrm{NO}$ \\
\hline 19 & Keystone Bank & 2001 & NIL & Yes & yes & NO \\
\hline 20 & Mainstreet Bank Ltd & 2006 & NIL & Yes & yes & $\mathrm{NO}$ \\
\hline 21 & $\begin{array}{l}\text { Heritage Banking } \\
\text { Company ltd }\end{array}$ & 2012 & NIL & Yes & yes & NO \\
\hline
\end{tabular}

Source: CBN ANNUAL REPORTS, VARIOUS BANKS ANNUAL REPORTS AND WEBSITES. 


\section{Macrothink}

International Journal of Accounting and Financial Reporting

ISSN 2162-3082

2016, Vol. 6, No. 1

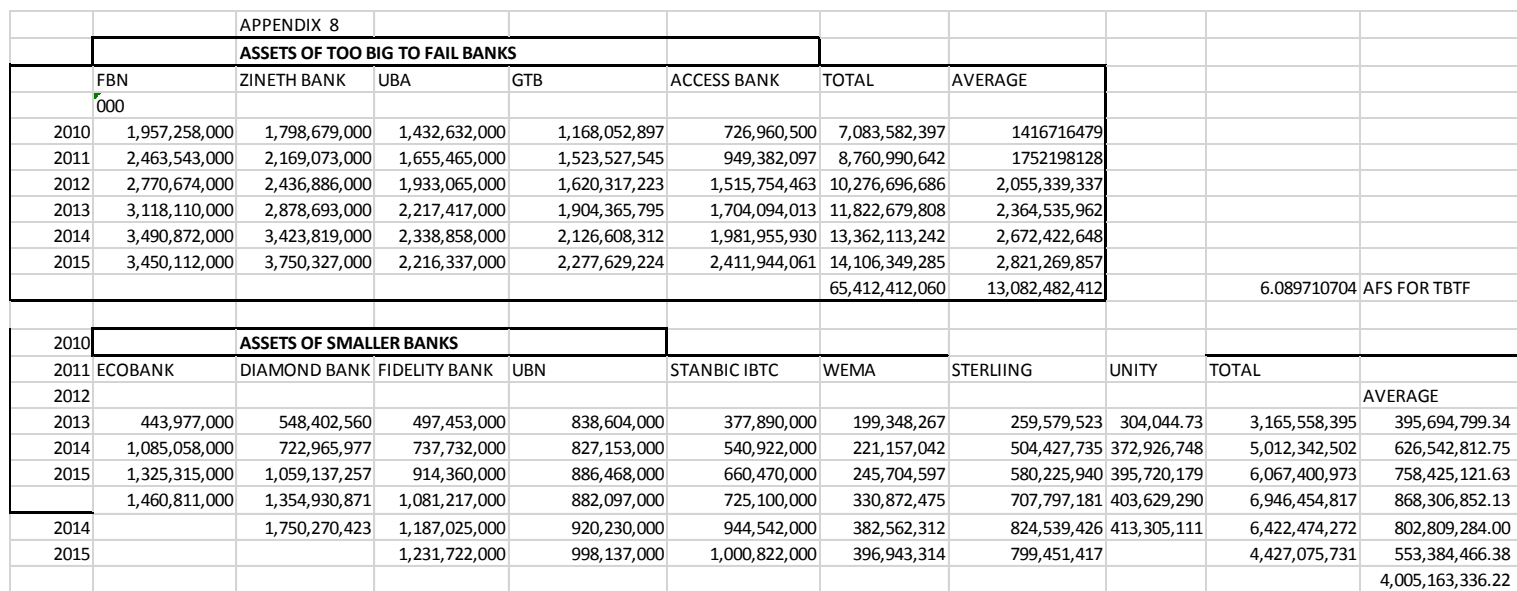

SAMPLE OF AVAILABL-E FOR- SALE FINANCIAL INSTRUMENTS (2010-2013) FOR SMALLER BANKS

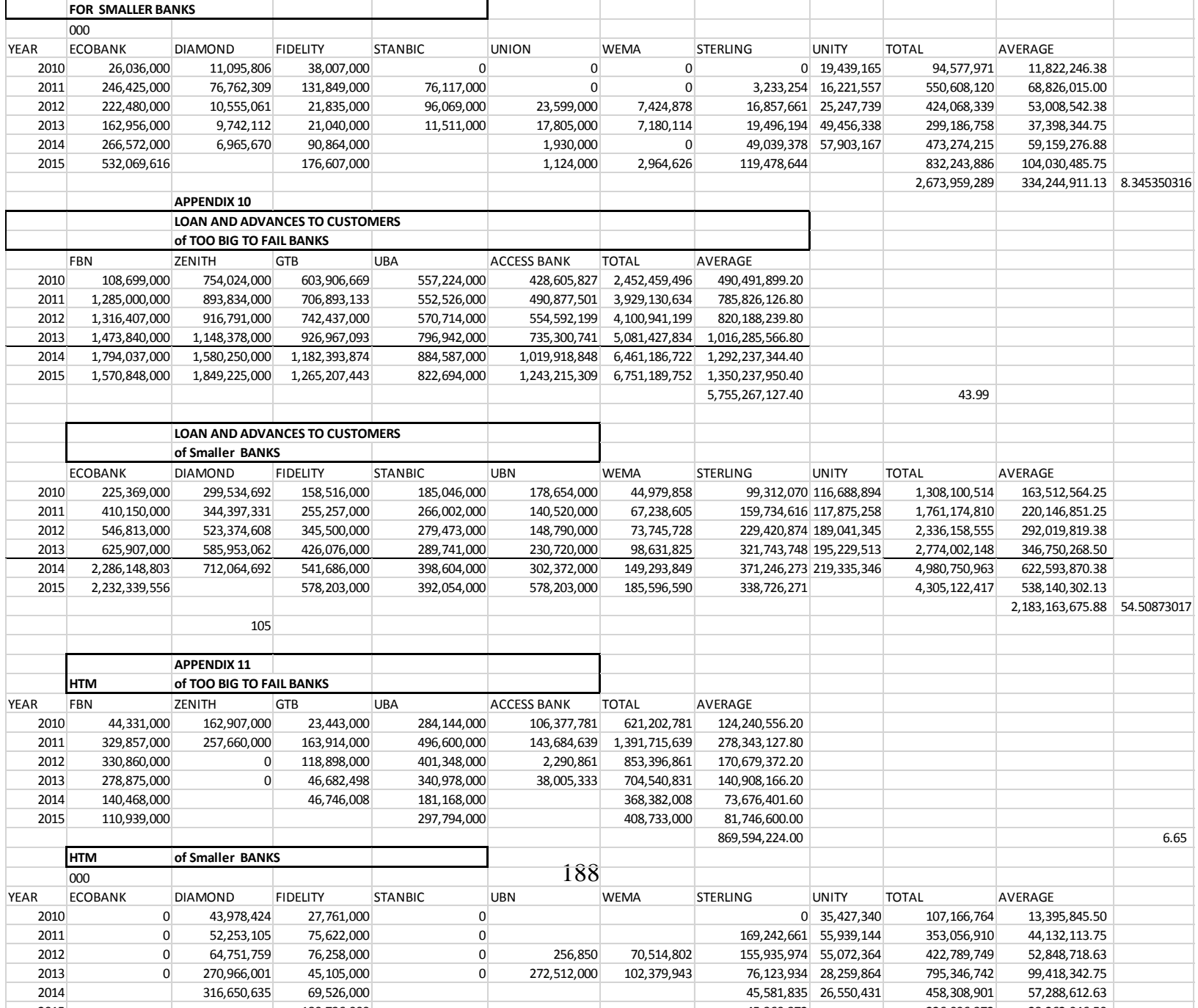




\begin{tabular}{|c|c|c|c|c|c|c|c|c|c|c|c|}
\hline & \multirow{2}{*}{\begin{tabular}{|l|} 
HTM \\
000
\end{tabular}} & \multicolumn{2}{|l|}{ of Smaller BANKS } & & & \multirow[b]{3}{*}{ WEMA } & \multirow[b]{3}{*}{ STERLING } & & \multirow[b]{3}{*}{ TOTAL } & \multirow[b]{3}{*}{ AVERAGE } & \\
\hline & & & & & \multirow[b]{2}{*}{ UBN } & & & \multirow[b]{2}{*}{ UNITY } & & & \\
\hline YEAR & ECOBANK & DIAMOND & FIDELITY & STANBIC & & & & & & & \\
\hline 2010 & 0 & $\quad 43,978,424$ & $27,761,000$ & 0 & & & 0 & $35,427,340$ & $\quad 107,166,764$ & $13,395,845.50$ & \\
\hline 2011 & 0 & $52,253,105$ & $75,622,000$ & 0 & & & $169,242,661$ & . $55,939,144$ & $353,056,910$ & $44,132,113.75$ & \\
\hline 2012 & 0 & $64,751,759$ & $76,258,000$ & 0 & 256,850 & $70,514,802$ & $155,935,974$ & $55,072,364$ & $422,789,749$ & $52,848,718.63$ & \\
\hline 2013 & 0 & $270,966,001$ & $45,105,000$ & 0 & $272,512,000$ & $102,379,943$ & $76,123,934$ & $28,259,864$ & $795,346,742$ & $99,418,342.75$ & \\
\hline 2014 & & $316,650,635$ & $69,526,000$ & & & & $45,581,835$ & $26,550,431$ & $458,308,901$ & $57,288,612.63$ & \\
\hline 2015 & & & $180,736,000$ & & & & $45,360,372$ & & $226,096,372$ & $28,262,046.50$ & \\
\hline & & & & & & & & & & $295,345,679.75$ & 7.374123224 \\
\hline & & 106 & & & & & & & & & \\
\hline & & & & & & & & & & & \\
\hline & & APPENDIX 12 & & & & & & & & & \\
\hline & HFT & of TOO BIG TO FA & AlL BANKS & & & & & & & & \\
\hline YEAR & FBN & ZENITH BANK & GTB & UBA & ACCESS BANK & TOTAL & & & & & \\
\hline 2010 & $11,485,000$ & 587,000 & $131,189,000$ & $1,267,000$ & $2,286,974$ & $146,814,974$ & $29,362,994.80$ & & & & \\
\hline 2011 & $2,552,000$ & 0 & $151,819,000$ & 237,000 & $1,056,706$ & $155,664,706$ & $31,132,941.20$ & & & & \\
\hline 2012 & $1,942,000$ & & $267,417,000$ & 456,000 & $49,659,614$ & $319,474,614$ & $63,894,922.80$ & & & & \\
\hline 2013 & $2,225,000$ & & $13,746,682$ & 777,000 & 819,940 & $17,568,622$ & $3,513,724.40$ & & & & \\
\hline 2014 & $9,258,000$ & & $5,675,545$ & $1,099,000$ & & $16,032,545$ & $3,206,509.00$ & & & & \\
\hline 2015 & $8,225,000$ & & $25,075,615$ & $11,249,000$ & & $44,549,615$ & $8,909,923.00$ & & & & \\
\hline & & & & & & $700,105,076$ & $140,021,015.20$ & & & & 1.07 \\
\hline & HFT & of Smaller BANK & & & & & & & & & \\
\hline YEAR & ECOBANK & DIAMOND & FIDELITY & UBN & STANBIC & WEMA & STERLING & UNITY & TOTAL & AVERAGE & \\
\hline 2010 & $6,821,000$ & $\quad 1,109,080$ & 0 & 0 & 0 & 0 & D & 0 & $7,930,080$ & $991,260.00$ & \\
\hline 2011 & $32,812,000$ & $8,041,618$ & $20,630,000$ & 0 & $66,476,000$ & 0 & 0 & 0 & $127,959,618$ & $15,994,952.25$ & \\
\hline 2012 & $23,394,000$ & $90,111,236$ & $201,806,000$ & 867,000 & $113,401,000$ & 0 & $1,998,860$ & 0 & $431,578,096$ & $53,947,262.00$ & \\
\hline 2013 & $17,881,000$ & $3,428,848$ & $254,909,000$ & $2,847,000$ & $40,711,000$ & 0 & $2,200,994$ & 0 & $321,977,842$ & $40,247,230.25$ & \\
\hline 2014 & & $3,481,299$ & $83,363,000$ & & & & $1,949,460$ & $2,793,700$ & $91,587,459$ & $11,448,432.38$ & \\
\hline 2015 & & & $4,070,000$ & & & & $4,692,636$ & & $8,762,636$ & $1,095,329.50$ & \\
\hline & & & & & & & & & & $123,724,466.38$ & 3.089124113 \\
\hline
\end{tabular}

\begin{tabular}{|rlrllrlr|}
\hline & FBN & ZINETH BANK & UBA & GTB & ACCESS BANK & \multicolumn{1}{l}{ TOTAL } & \multicolumn{1}{l|}{ AVERAGE } \\
& 000 & & & & & & \\
2010 & $1,957,258,000$ & $1,798,679,000$ & $1,432,632,000$ & $1,168,052,897$ & $726,960,500$ & $7,083,582,397$ & 1416716479 \\
2011 & $2,463,543,000$ & $2,169,073,000$ & $1,655,465,000$ & $1,523,527,545$ & $949,382,097$ & $8,760,990,642$ & 1752198128 \\
2012 & $2,770,674,000$ & $2,436,886,000$ & $1,933,065,000$ & $1,620,317,223$ & $1,515,754,463$ & $10,276,696,686$ & $2,055,339,337$ \\
2013 & $3,118,110,000$ & $2,878,693,000$ & $2,217,417,000$ & $1,904,365,795$ & $1,704,094,013$ & $11,822,679,808$ & $2,364,535,962$ \\
2014 & $3,490,872,000$ & $3,423,819,000$ & $2,338,858,000$ & $2,126,608,312$ & $1,981,955,930$ & $13,362,113,242$ & $2,672,422,648$ \\
2015 & $3,450,112,000$ & $3,750,327,000$ & $2,216,337,000$ & $2,277,629,224$ & $2,411,944,061$ & $14,106,349,285$ & $2,821,269,857$ \\
& & & & & & $65,412,412,060$ & $13,082,482,412$ \\
\hline
\end{tabular}

\section{Copyright Disclaimer}

Copyright for this article is retained by the author(s), with first publication rights granted to the journal.

This is an open-access article distributed under the terms and conditions of the Creative Commons Attribution license (http://creativecommons.org/licenses/by/3.0/). 